\title{
Epidemiology of typhoidal salmonellosis in childhood: the Pakistan country report
}

\author{
Zulfiqar A. Bhutta
}

\begin{abstract}
Abstrak
Pakistan mempunyai jumlah penduduk sebesar 136 juta, dan 67 juta di antaranya berusia kurang dari 18 tahun. Angka kematian pada kelompok Balita adalah 5 juta setiap tahun, dan sebetgian besar terjadi karena penyakit infeksi dengan penyakit diare serta penyakit saluran pernafasan sebagai penyebab utama dari kematian. Demam tifoid (DT) merupakan salah satu penyebab utama morbiditas pada penduduk yang tinggal di kota atau sekitarnya, dan meskipun tidak terdapat suatu data prevalensi yang pasti berdasarkan situasi masyarakat setempat, diperkirakan angka kejadian DT di Karachi adalah sebesar 500 kasus per 100.000 penduduk. Meskipun kadangkadang ditemukan adanya kasus-kasus yang resisten terhadap kloramfenikol untuk waktu yang cukup lama, pertengahan dasawarsa 1980-an ditandai dengan munculnya jenis kuman Salmonella typhi yang resisten terhadap tiga jenis antibiotika primer yang lazim dipergunakan. Kuman jenis MDR (multi-drug resistant) ini, yang pada permulaannya hanya sekitar 10-15\% dari semua isolat yang ditemukan, meningkat mencapai hampir 50\% pada tahun 1994/1995, sehingga memperberat beban untuk pembiayaan sektor. kesehatan. Jumlah kasus DT pada bayi diperkirakan sekitar $15 \%$ dari semua kasus anak-anak, tetapi kelompok ini mempunyai morbiditas dan mortalitas yang lebih besar, dengan manifestasi klinis atipik dan kelainan yang lebih berat pada kelompok bayi usia muda. Meskipun pada tahun 1996 dijumpai kecenderungan penurunan jumlah isolat Salmonella typhi yang MDR, jumlahnya masih mencapai angka $36 \%$ dari semua isolat. Mengingat keterbatasan dana untuk pengelolaan kasus, terapi yang tepat untuk kasus dengan MDR merupakan suatu problem khusus di Pakistan. Meskipun terapi dengan seftriakson i.v. ternyata efektif untuk kasus MDR, jenis pengobatan ini lebih mahal dibandingkan dengan pengobatan untuk kasus yang sensitif dan kadang-kadang memerlukan lama pengobatan melampaui 7 hari. Demikian pula terjadi masalah pada terapi dengan menggunakan kuinolon dengan timbulnya jenis kuman yang resisten. Semua hal ini mengarahkan kita untuk lebih memusatkan perhatian pada masalah strategi pencegahan demam tifoid.
\end{abstract}

\begin{abstract}
Pakistan has a population approximately 136 million people, of which 67 are under 18 years of age. Infectious diseases account for the majority of the 5 million deaths annually in children under 5 years of age, with diarrhea and acute respiratory ilnesses as the major killers. Typhoid fever is however a major cause of morbidity among the urban and peri-urban population, and although accurate community-based prevalence data is unavailable, it is estimated that the annual incidence of typhoid in Karachi is about 500 cases per 100,000 population. Although isolated cases of chloramphenicol resistance have been known for a long time, the mid 1980s saw the emergence of strains of Salmonella typhi to all the three primary oral antibiotics. These multi-drug resistant (MDR) strains initially accounted for 10-15\% of all isolates but rose to almost 50\% of of all cases of typhoid by 1994/1995, placing an enormous burden on already strained health resources. Although typhoid cases in infancy account for only $15 \%$ of all children, the morbidity and mortality is considerably greater, representing both atypical presentation as well as a greater severity of the disorder in younger infants. Although there are encouraging trends of a reduction in the relative proportion of MDR strains of typhoid in 1996, they still account for 38\% of all paediatric Salmonella typhi isolates. Given the limited resources available for cases management, appropriate antimicrobial therapy of MDR typhoid has posed particular problems in Pakistan. Although i.v ceftriaxone was shown to be effective in the therapy of MDR typhoid, it is prohibitively expensive and in contrast to infection with sensitive strains of typhoid, therapy for greater than 7 days is required. Therapy with oral quinolones has posed problem in recent years with emergence of resistant strains. It is imperative therefore that the focus clearly remain on preventive strategies for typhoid.
\end{abstract}

Department of Pediatrics, The Aga Khan University, Karachi, Pakistan. 